\title{
Microstructure and Oxidation Behavior of CrAl Laser-Coated Zircaloy-4 Alloy
}

\author{
Jeong-Min Kim ${ }^{1}{ }^{*}$, Tae-Hyung Ha ${ }^{1}$, Il-Hyun Kim ${ }^{2}$ and Hyun-Gil Kim ${ }^{2}$ \\ 1 Department of Advanced Materials Engineering, Hanbat National University, 125 Dongseo-daero, \\ Yuseong-gu, Daejeon 34158, Korea; htman15@naver.com \\ 2 Light Water Reactor Fuel Technology Division, Korea Atomic Energy Research Institute, \\ 989-111 Daedek-daero, Yuseong-gu, Daejeon 34057, Korea; s-weat@hanmail.net (I.-H.K.); \\ hgkim@kaeri.re.kr (H.-G.K.) \\ * Correspondence: jmk7475@hanbat.ac.kr; Tel.: +82-42-821-1235
}

Academic Editor: Hugo F. Lopez

Received: 24 October 2016; Accepted: 10 February 2017; Published: 15 February 2017

\begin{abstract}
Laser coating of a CrAl layer on Zircaloy-4 alloy was carried out for the surface protection of the $\mathrm{Zr}$ substrate at high temperatures, and its microstructural and thermal stability were investigated. Significant mixing of $\mathrm{CrAl}$ coating metal with the $\mathrm{Zr}$ substrate occurred during the laser surface treatment, and a rapidly solidified microstructure was obtained. A considerable degree of diffusion of solute atoms and some intermetallic compounds were observed to occur when the coated specimen was heated at a high temperature. Oxidation appears to proceed more preferentially at Zr-rich region than $\mathrm{Cr}$-rich region, and the incorporation of $\mathrm{Zr}$ into the $\mathrm{CrAl}$ coating layer deteriorates the oxidation resistance because of the formation of thermally unstable $\mathrm{Zr}$ oxides.
\end{abstract}

Keywords: laser coating; Zircaloy-4; CrAl; microstructure; oxidation

\section{Introduction}

Zirconium alloys have been widely used as nuclear materials because of their high chemical stability under the normal operating conditions of a pressurized or boiling water reactor, low absorption cross-section of thermal neutrons, and fairly good mechanical properties. However, $\mathrm{Zr}$ alloys are vulnerable to the high temperature oxidation that can occur in the case of accidents. Since explosive hydrogen is formed by the rapid zirconium oxidation, a reduced oxidation rate of $\mathrm{Zr}$ alloys at high temperatures is necessary to improve the accident tolerance [1-4]. As a short-term solution to the problem, protective coating through an efficient and economical method such as laser coating and thermal spray can be considered [2,4].

It has been previously reported that a laser coating of chromium on Zircaloy-4 cladding tube could enhance the high-temperature oxidation resistance significantly [2]. The diffusion of oxygen into the $\mathrm{Zr}$ substrate was observed to be effectively restricted by the $\mathrm{Cr}$ coating layer during the oxidation. When a coated alloy is exposed to a high temperature, a significant diffusion and microstructural variation may occur at the coating/substrate interface, even for a short time. In the case of laser-treated FeCrAl-coating on Mo alloy, an interfacial reaction was found to occur at high temperature [5].

Meanwhile, it was reported that $\mathrm{Cr}-\mathrm{Al}$ composite coatings were very effective in enhancing the oxidation resistance of metals at high temperatures [6]. Since $\mathrm{Al}_{2} \mathrm{O}_{3}$ and $\mathrm{Cr}_{2} \mathrm{O}_{3}$ can form on the surface of $\mathrm{Cr}-\mathrm{Al}$ coated alloys, the high temperature oxidation resistance is expected to increase even further. Although the superiority of $\mathrm{Cr}-\mathrm{Al}$ laser coating has already been demonstrated, research on the stability of the microstructure at high temperature is not yet sufficient. In the case of $\mathrm{Cr}$-coated $\mathrm{Zr}$ alloy, comparatively a few phases can be formed between $\mathrm{Cr}$ coating layer and $\mathrm{Zr}$ substrate according to the $\mathrm{Zr}$-Cr binary phase diagram [7]. However, in the case of $\mathrm{CrAl}-$ coated $\mathrm{Zr}$ alloy, more complicated 
interfacial reactions would occur during the solidification and when it is exposed to high temperatures. Therefore, in the present research, $\mathrm{CrAl}$ laser-coated $\mathrm{Zr}$ alloys were exposed to high temperatures, and then their microstructural variation and oxidation behavior were investigated.

\section{Materials and Methods}

Zircaloy-4 alloy (Zr-1.38\%Sn-0.2\%Fe-0.1\%Cr, wt. \%) sheets were used as the substrate, and $\mathrm{CrAl}$ (30 wt. \% Al) coating layer with the average thickness of about $300 \mu \mathrm{m}$ was deposited on the surface of the $\mathrm{Zr}$ alloy through a laser coating process. A photograph of the laser equipment for coating is shown in Figure 1. The laser coating was carried out by using a continuous wave (CW) diode laser (wavelength of $1062 \mathrm{~nm}$ ) with a maximum power of $300 \mathrm{~W}$ (PF-1500F model; HBL Co., Daejeon, Korea) and a power supply (Pwp14Y04K model; Yesystem Co., Daejeon, Korea). Coating process variables such as laser power, powder injection speed, specimen moving velocity, and gas flow speed were adjusted based on previous research results [8]. The applied power for the laser treatment ranged up to $300 \mathrm{~W}$, and the scanning speed was $14 \mathrm{~mm} / \mathrm{s}$. To prevent any oxidation during the process, an inert gas (Ar) was continuously blowing into the melted surface of specimen. The mean size of the $\mathrm{CrAl}$ alloy powders as a raw material for coating was $90 \mu \mathrm{m}$.

As previously mentioned, when used for nuclear fuel claddings or the like, it can be accidently exposed to a high temperature for a long time, and it is presumed that the atmosphere is mainly water vapor. For ease of experiment, firstly, microstructural variations of the laser-coated specimens were investigated under argon or air atmosphere at $1100{ }^{\circ} \mathrm{C}$ for different holding times. Then, oxidation test of the $\mathrm{CrAl}$ and $\mathrm{CrAlZr}$ alloys was conducted in the steam atmosphere at $1200{ }^{\circ} \mathrm{C}$ for $1 \mathrm{~h}$. Cr-30 wt. \% Al and $\mathrm{Cr}-30 \mathrm{wt}$. \% Al-20 wt. \% Zr alloy specimens were prepared through vacuum arc remelting process to directly investigate the characteristics of the coating layers without Zr substrate. Microstructural analyses were performed using SEM (JEOL, Tokyo, Japan) equipped with an energy dispersive X-ray spectrometer (EDS, JEOL, Tokyo, Japan), and an X-ray diffractometer (XRD, Rigaku, Tokyo, Japan).

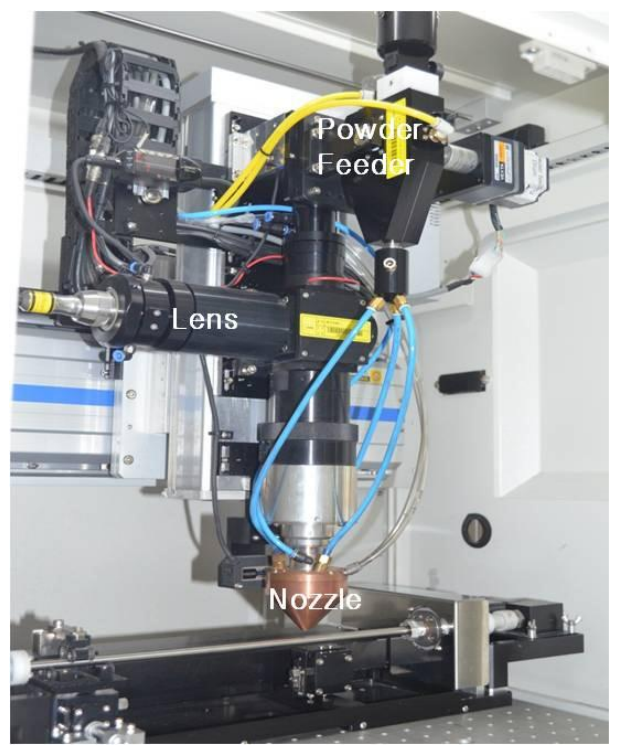

Figure 1. Appearance of the laser equipment for coating.

\section{Results and Discussion}

\subsection{Micorstucture of CrAl Laser-Coated Zr Alloy}

Figure 2 shows SEM micrographs of CrAl laser coating layers on Zircaloy-4 alloy. Some $\mathrm{Zr}$ content could be measured in the $\mathrm{CrAl}$ coating layer that is far away from the $\mathrm{Zr}$ substrate (sometimes even near the coating surface), implying that significant intermixing of CrAl coating and Zr substrate 
occurred during the laser coating. The light bottom area is $\mathrm{Zr}$ substrate, and the $\mathrm{Zr}$ content is increased as distance from the substrate is increased. A Zr-rich region appears between the Zr substrate and the $\mathrm{CrAl}$ coating layer. The composition of the $\mathrm{Zr}$-rich part indicates the formation of a solid solution of $\mathrm{Cr}$ and $\mathrm{Al}$ in $\mathrm{Zr}$. As indicated in Figure 2b, the majority of the Cr-rich coating layer is composed of two rapidly solidified regions: $\mathrm{Cr}$-rich and $\mathrm{AlZr}(\mathrm{Cr})$ phases.

\begin{tabular}{|c|c|c|}
\hline Element & at. $\%$ \\
\hline $\mathrm{Zr}$ & 69.64 \\
\hline $\mathrm{Cr}$ & 17.10 \\
\hline $\mathrm{Al}$ & 13.26 \\
\hline $\mathrm{Zr}$ & 21.60 \\
\hline $\mathrm{Cr}$ & 43.81 \\
\hline $\mathrm{Al}$ & 34.59 \\
\hline
\end{tabular}

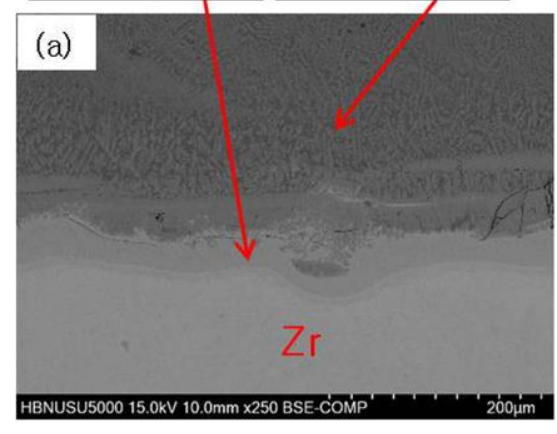

\begin{tabular}{|c|c|c|c|c|}
\hline Element & at. $\%$ & Element & at $\%$ \\
\hline $\mathrm{Zr}$ & 14.24 \\
\hline $\mathrm{Cr}$ & 44.99 \\
\hline $\mathrm{Zl}$ & 40.77 \\
\hline $\mathrm{Cr}$ & 60.21 \\
\hline $\mathrm{Al}$ & 35.38 \\
\hline
\end{tabular}

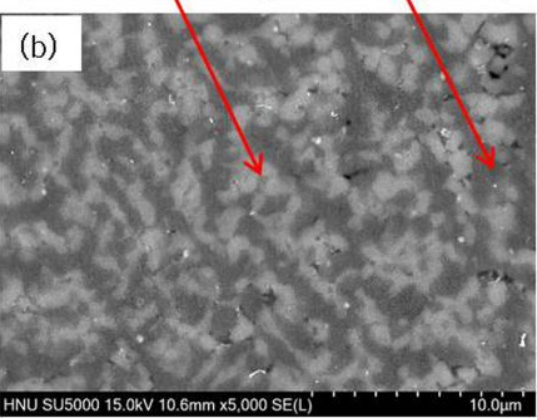

Figure 2. SEM-EDS (scanning electron microscopy-energy dispersive X-ray spectrometry) analysis results of $\mathrm{CrAl}$ laser-coated Zircaloy-4 substrate alloy: (a) near the Zr substrate; (b) Cr-rich coating layer.

If the mixture of $\mathrm{CrAl}$ coating powders and the top surface of substrate were completely melted and homogeneous, primary $\mathrm{Cr}$ phase would be formed first from the liquid, since the major component of the surface liquid pool was Cr. Normal solidification reactions to form phases for Cr-30 wt. \% Al-20 wt. \% Zr alloy (approximate chemical composition for the majority of the Cr-rich coating layer) predicted by Pandat thermo-calculation program are as follows [9]:

1. Liquid $\rightarrow \mathrm{Cr}$ at $1492-1283^{\circ} \mathrm{C}$

2. Liquid $\rightarrow \mathrm{Cr}+\mathrm{Al}_{2} \mathrm{Zr}$ at $1283-1255^{\circ} \mathrm{C}$

3. Liquid $+\mathrm{Al}_{2} \mathrm{Zr} \rightarrow \mathrm{Cr}+\mathrm{Al}_{3} \mathrm{Zr}$ at $1255^{\circ} \mathrm{C}$

4. Liquid $\rightarrow \mathrm{Cr}+\mathrm{Al}_{3} \mathrm{Zr}$ at $1255-1238^{\circ} \mathrm{C}$

5. Liquid $\rightarrow \mathrm{Cr}+\mathrm{Al}_{3} \mathrm{Zr}+\mathrm{Al}_{8} \mathrm{Cr}_{5}$ at $1238^{\circ} \mathrm{C}$

$\mathrm{Cr}$ dendrites and the $\mathrm{Cr}+\mathrm{AlZr}$ eutectics should have formed upon solidification, however. The micrograph of the $\mathrm{Cr}$-rich coating layer in Figure $2 \mathrm{~b}$ reveals a somewhat different microstructure. Namely, dendritic primary $\mathrm{Cr}$ and $\mathrm{AlCr}$ phases were not observed. Additionally, in the case of the $\mathrm{AlZr}$ phase, it shows a dendritic morphology. This discrepancy seems to be because the growth occurred under a rapid solidification condition [10].

\subsection{CrAl Laser-Coated Zr Alloy that Exposed to a High Temperature}

Since the CrAl-coated $\mathrm{Zr}$ alloy is aimed to be resistant at high temperatures, the coated specimen was isothermally heated in inert atmosphere at $1100{ }^{\circ} \mathrm{C}$ for different times. Figure 3 indicates that inter-diffusion among phases in the coating layers apparently occurred after $2 \mathrm{~h}$. The diffusion of aluminum appears to be significant so that the aluminum content can be detected in the Zr substrate. Generally, three distinct parts are shown: Zr-substrate, Zr-rich area, Cr-rich area (the majority of the coating layer). An intermediate area between the $\mathrm{Zr}$-rich and $\mathrm{Cr}$-rich area may be counted, but it was excluded as it can be regarded as a part of the $\mathrm{Zr}$-rich area. 


\begin{tabular}{|c|c||c|c|}
\hline Element & at $\%$ & Element & at $\%$ \\
\hline $\mathrm{Zr}$ & 95.08 \\
\hline $\mathrm{Cr}$ & 0.42 \\
\hline $\mathrm{Zr}$ & 38.21 \\
\hline $\mathrm{Cl}$ & 4.50 \\
\hline $\mathrm{Cr}$ & 34.29 \\
\hline $\mathrm{Al}$ & 27.50 \\
\hline
\end{tabular}

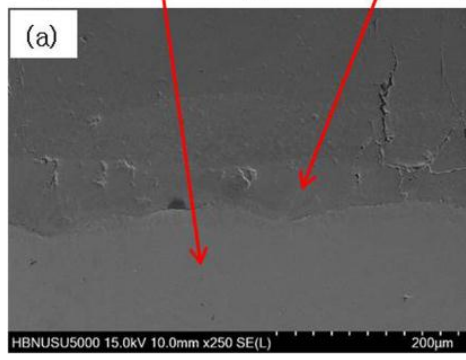

\begin{tabular}{|c|c||c|c|}
\hline Element & at $\%$ & Element & at $\%$ \\
\hline $\mathrm{Zr}$ & 32.98 \\
\hline $\mathrm{Cr}$ & 30.64 \\
\hline $\mathrm{Zr}$ & 21.25 \\
\hline $\mathrm{Al}$ & 36.38 \\
\hline $\mathrm{Cr}$ & 41.00 \\
\hline $\mathrm{Al}$ & 37.75 \\
\hline
\end{tabular}

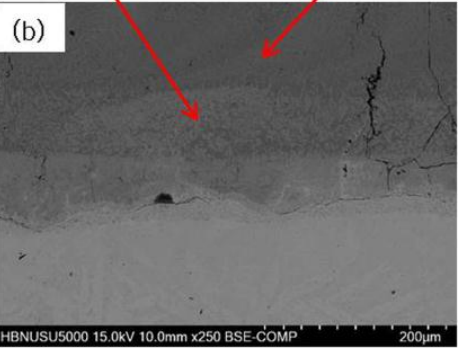

Figure 3. SEM-EDS analyses of laser-coated Zircaloy-4 substrate alloy after the isothermal heating at $1100{ }^{\circ} \mathrm{C}$ for $2 \mathrm{~h}$ in inert atmosphere: (a) bright image; (b) backscattered image.

As indicated in Figure 4, the isothermal heating clarified that the microstructure of the Zr-rich region near the substrate is composed of two regions: $\mathrm{Zr}$-rich and $\mathrm{Cr}$-rich. The $\mathrm{Zr}$-rich area is $\mathrm{Zr}$ phase, and the $\mathrm{Cr}$-rich area is postulated to be $\mathrm{CrZr}$ plus $\mathrm{AlZr}$ phases. Figure 5 also shows that the $\mathrm{Cr}$-rich area is composed of three distinct phases. The main phase is $\mathrm{Cr}$, containing about 40 at. \% $\mathrm{Al}$ that is near the maximum solubility limit for $\mathrm{Cr}$ at $1100{ }^{\circ} \mathrm{C}$. Others are Al-rich phases that include relatively large or very limited $\mathrm{Zr}$ content. According to the Pandat prediction and literature [9,11,12], the Al-rich phases with large $\mathrm{Zr}$ contents seem to be $\mathrm{Al}_{3} \mathrm{Zr}$. Meanwhile, the Al-rich phase with a very low $\mathrm{Zr}$ content should be $\mathrm{Al}_{8} \mathrm{Cr}_{5}$. The microstructure of the coated specimens isothermally heated for $10 \mathrm{~h}$ was also investigated. However, the coated specimens maintained for $10 \mathrm{~h}$ showed similar microstructural characteristics to those of specimens held for $2 \mathrm{~h}$. It is believed that the microstructure of the coating layer could be converted into near the equilibrium structure even with a holding time of just $2 \mathrm{~h}$, since $1100{ }^{\circ} \mathrm{C}$ is a very high temperature.

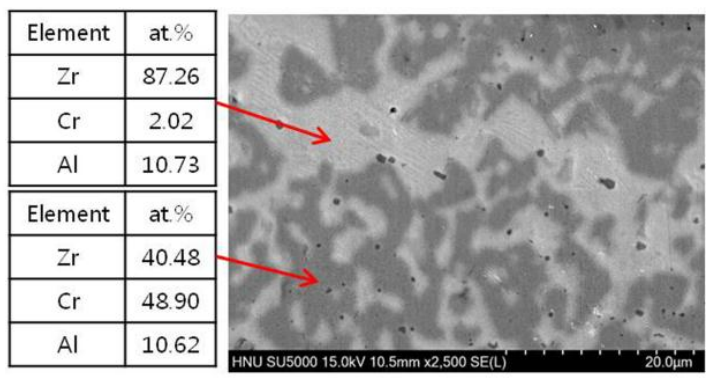

Figure 4. SEM-EDS analyses of Zr-rich area of CrAl-coated Zircaloy-4 alloy after the isothermal heating at $1100{ }^{\circ} \mathrm{C}$ for $2 \mathrm{~h}$ in inert atmosphere.

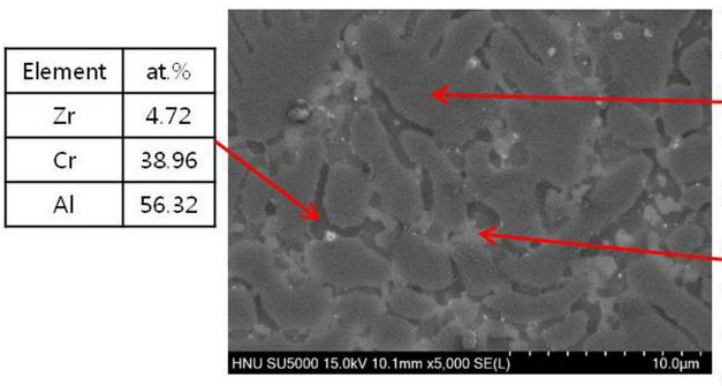

\begin{tabular}{|c|c|}
\hline Element & at $\%$ \\
\hline $\mathrm{Zr}$ & 1.34 \\
\hline $\mathrm{Cr}$ & 60.45 \\
\hline $\mathrm{Al}$ & 38.21 \\
\hline \hline Element & at $\%$ \\
\hline $\mathrm{Zr}$ & 23.17 \\
\hline $\mathrm{Cr}$ & 19.83 \\
\hline $\mathrm{Al}$ & 57.00 \\
\hline
\end{tabular}

Figure 5. SEM-EDS analyses of $\mathrm{CrAl}$ coating layer on Zircaloy-4 alloy after the isothermal heating at $1100{ }^{\circ} \mathrm{C}$ for $2 \mathrm{~h}$ in inert atmosphere. 
The chemical composition distribution as a function of depth for the CrAl-coated specimen exposed to a high temperature air is shown in Figure 6. Like Figure 3, three distinct parts are generally observed in the specimen, and it is clear that oxidation proceeded a little, only at the surface. If cracks are formed in the coating layer, they are undoubtedly undesirable, because the protective coating may be detached from the substrate. Vertically-formed cracks are supposed to be more detrimental to oxidation resistance, since oxygen ions can move easily through the cracks into the substrate. The formation of $\mathrm{Zr}$ oxides was observed on the $\mathrm{Zr}$ substrate near a vertical crack, as shown in Figure 7 . However, a significant oxygen content was measured only at the top surface of $\mathrm{CrAl}$ coating layer in the sound region, and this suggests that the $\mathrm{CrAl}$ coating layer was effective in delaying the high temperature oxidation. It also appears that $\mathrm{Al}$ and $\mathrm{Zr}$ oxidize more preferentially than $\mathrm{Cr}$ in the coating layer. Unlike $\mathrm{Al}$ oxides, $\mathrm{Zr}$ oxides are not protective against oxidation toward the matrix at high temperatures [1,2]. Therefore, a mixing between $\mathrm{CrAl}$ coating layer and $\mathrm{Zr}$ substrate should be carefully controlled to minimize the $\mathrm{Zr}$ content at the top of the surface coating layer.

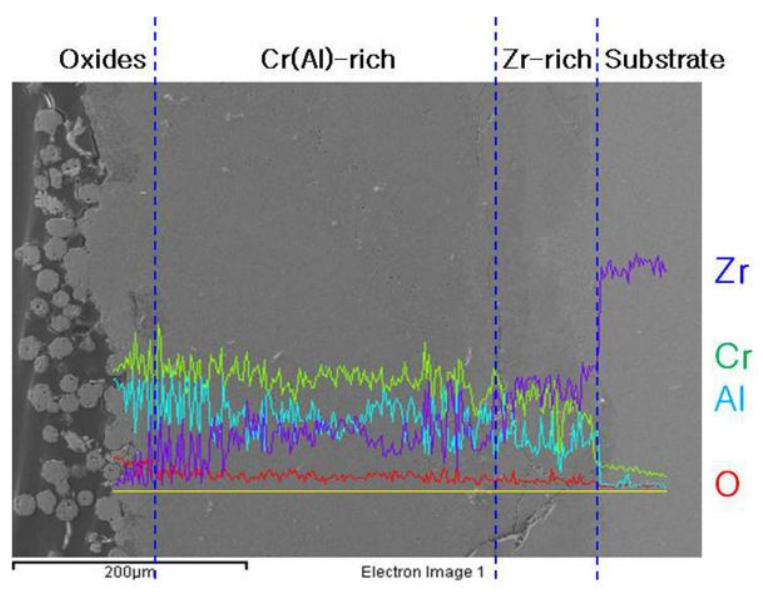

Figure 6. SEM micrographs with EDS profiles of the oxidized CrAl coating layer on Zircaloy-4 after isothermal heating at $1100{ }^{\circ} \mathrm{C}$ for $10 \mathrm{~min}$ in air.

\begin{tabular}{|c|c||c|c|}
\hline Element & at $\%$ & Element & at $\%$ \\
\hline $\mathrm{O}$ & 67.12 & $\mathrm{O}$ & 67.62 \\
\hline $\mathrm{Zr}$ & 30.89 & $\mathrm{Zr}$ & 11.48 \\
\hline $\mathrm{Cr}$ & - & $\mathrm{Cr}$ & 16.18 \\
\hline $\mathrm{Al}$ & 1.99 & $\mathrm{Al}$ & 4.72 \\
\hline
\end{tabular}

\begin{tabular}{|c|c||c|c|}
\hline Element & at $\%$ & Element & at $\%$ \\
\hline $\mathrm{O}$ & 11.15 & $\mathrm{O}$ & 66.84 \\
\hline $\mathrm{Zr}$ & 0.75 & $\mathrm{Zr}$ & 3.15 \\
\hline $\mathrm{Cr}$ & 68.45 & $\mathrm{Cr}$ & 2.31 \\
\hline $\mathrm{Al}$ & 19.64 & $\mathrm{Al}$ & 27.70 \\
\hline
\end{tabular}
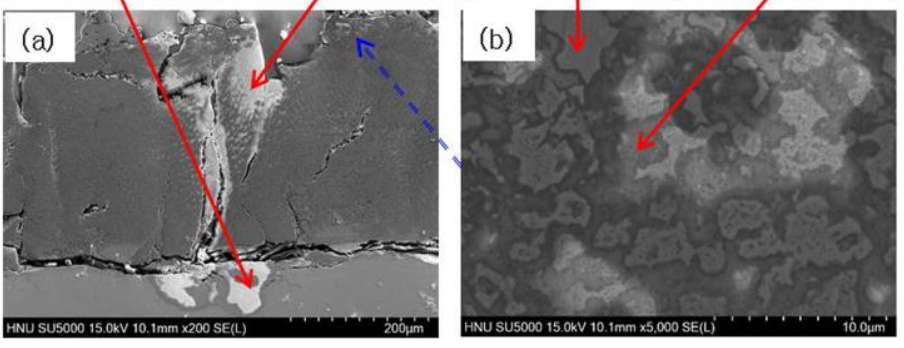

Figure 7. SEM-EDS analyses of laser coated Zircaloy-4 substrate alloy after isothermal heating at $1100{ }^{\circ} \mathrm{C}$ for $30 \mathrm{~min}$ in air: (a) near the substrate; (b) top surface of the coating layer.

\subsection{Oxidation Behavior of $\mathrm{CrAl}$ Laser-Coated Zr Alloy at High Temperature}

To clearly compare the oxidation resistance of $\mathrm{CrAl}$ coating layer with that of the $\mathrm{Zr}$-incorporated CrAl layer, $\mathrm{Cr}-30$ wt. \% Al and Cr-30 wt. \% Al-20 wt. \% Zr alloy cast specimens were fabricated by vacuum arc remelting, and an oxidation test in steam at $1200{ }^{\circ} \mathrm{C}$ for $1 \mathrm{~h}$ was carried out. In the 
case of accident, the temperature for nuclear cladding can be extremely increased, and is expected to be still under steam atmosphere. The corrosion resistance under atmosphere containing moisture can be quite different from that under dry air. Although $\mathrm{Si}$ and $\mathrm{SiO}_{2}$ are highly corrosion-resistant materials, they were quickly dissolved in a pressurized water condition at $360{ }^{\circ} \mathrm{C}$ in $18.9 \mathrm{MPa}$ [2]. As shown in Figure 8, the coating layer without $\mathrm{Zr}$ possesses remarkably higher oxidation resistance than the Zr-mixed layer. Namely, much higher weight gain was observed for the Zr-containing alloy as compared to the $\mathrm{CrAl}$ alloy without Zr. The oxidation behavior for $\mathrm{ZrCr} 30 \mathrm{Al}$ specimen (Zr alloy containing $30 \mathrm{wt}$. \% $\mathrm{Cr}$ and $20 \mathrm{wt}$. \% Al) was also compared for reference. Even though $\mathrm{Cr}$ and $\mathrm{Al}$ are contained in large amounts, it can be confirmed that the $\mathrm{Zr}$ alloy is seriously oxidized in a high temperature steam atmosphere.

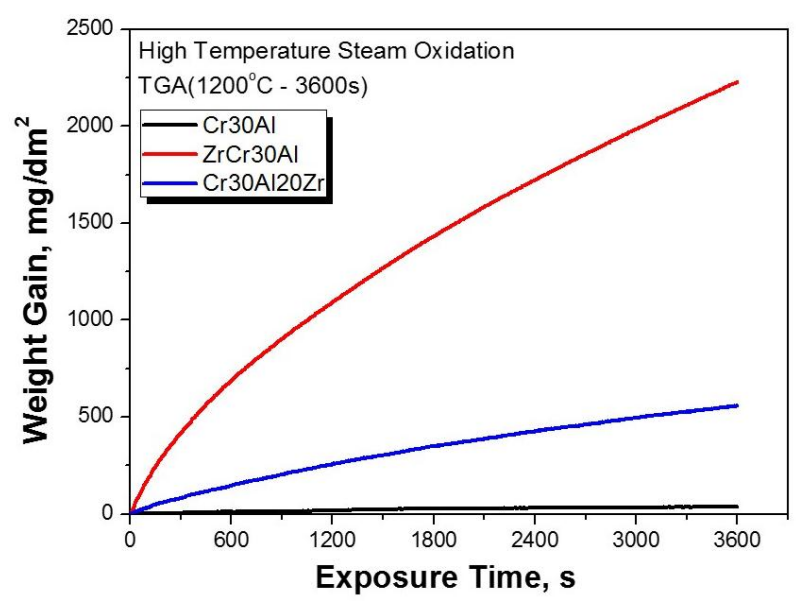

Figure 8. Oxidation behavior of $\mathrm{Cr}-30 \% \mathrm{Al}$ cast alloys with and without $\mathrm{Zr}$ after the steam oxidation test at $1200^{\circ} \mathrm{C}$ for $1 \mathrm{~h}$ ( $\mathrm{Zr}$ alloy containing $\mathrm{Cr}$ and $\mathrm{Al}$ is also compared for reference).

Figure 9 indicates that a stable $\mathrm{Al}_{2} \mathrm{O}_{3}$ phase is observed a lot in the surface of the $\mathrm{Cr}-30 \% \mathrm{Al}$ alloy. It is worth mentioning that a $\mathrm{Cr}_{2} \mathrm{O}_{3}$ phase was not found in that specimen. Although both $\mathrm{Cr}_{2} \mathrm{O}_{3}$ and $\mathrm{Al}_{2} \mathrm{O}_{3}$ phases are generally stable, the $\mathrm{Al}_{2} \mathrm{O}_{3}$ phase is believed to be more stable, resulting in a continuous external $\mathrm{Al}_{2} \mathrm{O}_{3}$ layer. This phenomenon has been known as transient oxidation [13]. If the content of aluminum in the coating layer is insufficient, it is considered that the $\mathrm{Cr}_{2} \mathrm{O}_{3}$ is observed on the coating surface. Meanwhile, a significant amount of $\mathrm{ZrO}_{2}$ and $\mathrm{Al}_{2} \mathrm{O}_{3}$ phases were found in the case of the $\mathrm{Zr}$-added alloy. Since the $\mathrm{Zr}$ oxide is not protective, the existence of a surface $\mathrm{ZrO}_{2}$ layer should be responsible for the comparatively lower oxidation resistance.
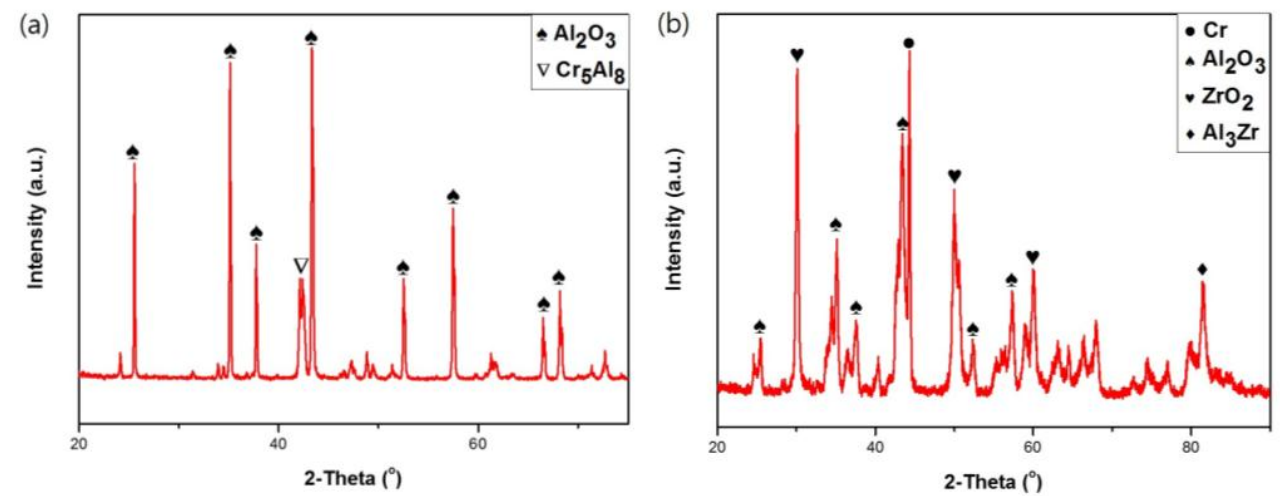

Figure 9. XRD analyses of cast specimens after the steam oxidation test at $1200{ }^{\circ} \mathrm{C}$ for $1 \mathrm{~h}$ : (a) $\mathrm{Cr}-30 \% \mathrm{Al}$; (b) $\mathrm{Cr}-30 \% \mathrm{Al}-20 \% \mathrm{Zr}$ alloy. 


\section{Conclusions}

It was found that a significant mixing between the $\mathrm{CrAl}$ layer and the $\mathrm{Zr}$ substrate and the formation of rapidly solidified microstructure occurred during the laser surface coating process. Inter-diffusions among the solidified phases took place when the coated specimens were isothermally heated at $1100{ }^{\circ} \mathrm{C}$, and resulted in the formation of equilibrium phases after just $2 \mathrm{~h}$. Since $\mathrm{Zr}$ is easily oxidized and $\mathrm{Zr}$ oxides are not protective against oxidation, the $\mathrm{Zr}$ content at the top of coating layer should be minimized to avoid deteriorated oxidation resistance.

Acknowledgments: This work was supported by the National Research Foundation of Korea (NRF) grant funded by Korea government (MSIP) (NRF-2012M2A8A5025822).

Author Contributions: J.-M.K. designed the research and wrote the manuscript with help from the other authors; T.-H.H. and I.-H.K. performed experiments; J.-M.K. and H.-G.K. analyzed the data.

Conflicts of Interest: The authors declare no conflict of interest.

\section{References}

1. Kuprin, A.S.; Belous, V.A.; Voyevodin, V.N.; Bryk, V.V.; Vasilenko, R.L.; Ovcharenko, V.D.; Reshetnyak, E.N.; Tolmachova, G.N.; Vyugov, P.N. Vacuum-arc chromium-based coatings for protection of zirconium alloys from the high temperature oxidation in air. J. Nucl. Mater. 2015, 465, 400-406. [CrossRef]

2. Kim, H.G.; Kim, I.H.; Jung, Y.I.; Park, D.J.; Park, J.Y.; Koo, Y.H. Adhesion property and high-temperature oxidation behavior of Cr-coated Zircaloy-4 cladding tube prepared by 3D laser coating. J. Nucl. Mater. 2015, 465, 531-539. [CrossRef]

3. Terrani, K.A.; Parish, C.M.; Shin, D.; Pint, B.A. Protection of zirconium by alumina- and chromia-forming iron alloys under high-temperature steam exposure. J. Nucl. Mater. 2013, 438, 64-71. [CrossRef]

4. Jin, D.; Yang, F.; Zou, Z.; Gu, L.; Zhao, X.; Guo, F.; Xiao, P. A study of the zirconium alloy protection by $\mathrm{Cr}_{2} \mathrm{C}_{2}$-NiCr coating for nuclear reactor application. Surf. Coat. Technol. 2016, 287, 55-60. [CrossRef]

5. Kim, J.M.; Ha, T.H.; Park, J.S.; Kim, H.G. Effect of laser surface treatment on the corrosion behavior of FeCrAl-coated TZM alloy. Metals 2016, 6, 29. [CrossRef]

6. Chen, C.; Zhang, J.; Duan, C.; Feng, X.; Shen, Y. Investigation of Cr-Al composite coatings fabricated on pure Ti substrate via mechanical alloying method: Effects of $\mathrm{Cr}$-Al ratio and milling time on coating, and oxidation behavior of coating. J. Alloy. Compd. 2016, 660, 208-219. [CrossRef]

7. Gonzalez, R.O.; Gribaudo, L.M. Analysis of controversial zones of the Zr-Cr equilibrium diagram. J. Nucl. Mater. 2005, 342, 14-19. [CrossRef]

8. Kim, H.G.; Kim, I.H.; Jung, Y.I.; Park, D.J.; Park, J.Y.; Koo, Y.H. High temperature oxidation behavior of Cr-coated zirconium. In Proceedings of the LWR fuel performance meeting, Charlotte, NC, USA, 15-19 September 2013; p. 840.

9. PANDAT. CompuTherm, LLC, Madison, WI, USA. Available online: http://www.computherm.com (accessed on 13 February 2017).

10. Yue, T.M.; Xie, H.; Lin, X.; Yang, H.O. Phase evolution and dendritic growth in laser cladding of aluminium on zirconium. J. Alloy. Compd. 2011, 509, 3705-3710. [CrossRef]

11. Okamoto, H. Phase diagrams for binary alloys. In ASM Desk Handbook; ASM International: Materials Park, $\mathrm{OH}, \mathrm{USA}, 2000$.

12. Zhang, M.; Xu, B.; Ling, G. Preparation and characterization of $\alpha-\mathrm{Al}_{2} \mathrm{O}_{3}$ film by low temperature thermal oxidation of $\mathrm{Al}_{8} \mathrm{Cr}_{5}$ coating. Appl. Surf. Sci. 2015, 331,1-7. [CrossRef]

13. Birks, N.; Meier, G.H.; Pettit, F.S. Introduction to the High-Temperature Oxidation of Metals; Cambridge University Press: Cambridge, UK, 2006; pp. 101-162.

(c) 2017 by the authors; licensee MDPI, Basel, Switzerland. This article is an open access article distributed under the terms and conditions of the Creative Commons Attribution (CC BY) license (http:/ / creativecommons.org/licenses/by/4.0/). 